\title{
鉛直管内固気二相旋回流における 粒子の流動特性の研究
}

\section{Research of Particle Behavior for Gas-Solid Swirling Flow in a Vertical Pipeline}

Measurements of particle velocity and concentration profiles for a swirling gas - solid flow in a vertical pipeline with a height of $12 \mathrm{~m}$ and an inner diameter of $80 \mathrm{~mm}$ have been performed by photographic methods. Polyethylene pellets with mean diameter of $3.2 \mathrm{~mm}$ were used as test particles. The initial swirl numbers were varied from 0.38 to 0.94 , the mean air velocities from $9 \mathrm{~m} / \mathrm{s}$ to $25 \mathrm{~m} / \mathrm{s}$ and the solid-gas ratios from 0.2 to 0.7 . It was found that in the acceleration region the mean particle velocity for the swirling gas-solid flow was higher than that for the axial gas-solid flow in the lower air velocity range and was lower in the higher air velocity range. Along the axial direction the change of the mean particle velocity for the swirling gas-solid flow was larger than that for the axial gas-solid flow in the acceleration region. With swirling flow, the particle velocity profiles became uniform.

Key Wards : Particle Concentration, Gas-Solid Two- Phase Flow, Pipeline, Particle Velocity, Swirling Flow

\section{1. 緒言}

著者ら ${ }^{(2)}$ は水平と鉛直管空気輸送に対して, 輸送 エネルギーの節約, 最適輸送速度の減少, 輸送の安定 性などという観点から旋回流空気輸送システムを提案 した。そして, 低速旋回流空気輸送では, 圧力損失や 閉塞の恐れが減少することを明らかにした。

旋回流空気輸送の応用においては, 合理的な旋回流 を使用して, 輸送エネルギーを減少することが重要で ある。そのためには, 固気二相旋回流の流動機構を十 分研究することが必要である。一般に, 輸送管内の固 体粒子の運動は三次元的であり, 旋回流空気輸送で は粒子の運動はより複雑になると考えられる。著者 $ら^{7.81}$ は低濃度の水平管内固気二相旋回流の実験を行 い，粒子の速度と濃度分布の特性を調へた。さらに, 旋回流中における粒子の運動および旋回流は粒子に影

1999 年 4 月 20 日受付

* 鹿児島大学工学部

（テ890-0065 鹿児島市郡元 1-21-40） TEL 099-285-8252

Faculty of Engineering, Kagoshima University

(1-21-40, Korimoto, Kagoshima 890-0065)

**九州工業大学工学部

（宁804-5500 北九州市戸畑区仙水町 1-1）TEL 093-884-3157

Kyushu Institute of Technology

(1-1, Sensui-cho, Tobata-ku, Kitakyusyu 804-5500)
響されることを調べるため，加速域を含む水平と鉛直 管内の三次元固気二相旋回流の数値シミュレーション を行った ${ }^{9,10)}$

本研究では, 低濃度の鉛直管内固気二相旋回流の実 験を行い, 固体粒子の運動軌跡の写真から粒子の速度 之濃度分布およびそれらの場所的な変化を供給器から $0.7 \mathrm{~m}, 5.7 \mathrm{~m}$ および $11.7 \mathrm{~m}$ 下流において測定し，そ の測定結果を検討し, 旋回流空気輸送における粒子の 流動特性を調べた。

\section{2. 実験装置および測定方法}

本研究に使用した実験装置は, Fig. 1 に示す圧送式 空気輸送システムを採用した。ブロワー11からの空気 は, 空気流量調節バルブ(2), 多孔整流板(3), 四分円) ズル(4)を通過した後, 旋回流発生器(6によって（直線 流の場合には, 旋回流発生器がない）旋回流に変えら れて輸送管(7)に入る。粒子は供給器(9)ら輸送管内に 入る。輸送管は内径 $D=80 \mathrm{~mm}$ のアクリルパイプか ら成り, 全長約 $H=12 \mathrm{~m}$ である。被輸送物の供給量 はバルブで調節する。輸送管内の空気流量は四分円ノ ズル（差圧変換器と圧力変換器を使用）で測定し, こ れから平均空気速度 $U_{\mathrm{a}}$ を算出した。粒子の質量流量 $G_{\mathrm{s}}$ は回収タンク(11)に取り付けられたロードセル(12)に 
(1) Blower

(2) Flow control valve

(3) Honeycomb

(4) Orifice meter

(5) Pressure transducer

(6) Swirler

(7) Conveying pipe

(8) Solids control valve

(9) Solids feed tank

(10) Connecting pipe

(11) Solids receiver

(12) Load cell

(13) Cyclone separator

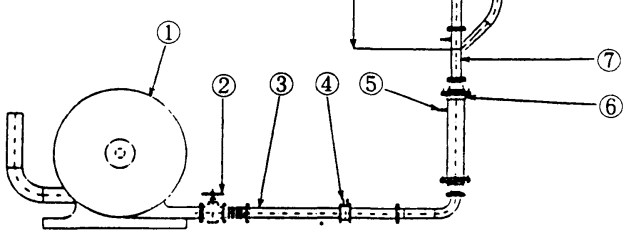

Fig. 1 Experimental apparatus

よって測定する。なお回は回収管である。

旋回流は案内羽根式発生器によって発生させる。旋 回流の強さの表示法として前報 ${ }^{11)}$ と同じく, 次式の 粒子供給断面のスワール数 $S_{0}$ (入口スワール数）を使 用する。

$$
S_{0}=\frac{2 \pi \rho \int_{0}^{R} u w r^{2} \mathrm{~d} r}{2 \pi \rho R \int_{0}^{R} u^{2} r \mathrm{~d} r}
$$

ここで, $u, w$ は空気速度の軸および円周方向成分, $R$ は管半径, $r$ は半径座標, $\rho$ は空気密度である。

実験は，旋回流之直線流において，粒子質量流量を $G_{\mathrm{s}}=0.03 \mathrm{~kg} / \mathrm{s}$ に保って行った。粒子速度と濃度分布 の測定は，粒子供給点から $x=0.7 \mathrm{~m}, x=5.7 \mathrm{~m}$ およ び $x=11.7 \mathrm{~m}$ 下流の長さ約 $250 \mathrm{~mm}$ の区間で行った。 カメラによって, 粒子の流動状態を撮影した。カメラ のシャッター速度は $2 \mathrm{~ms}$ である。撮影した粒子の流 動写真を拡大し, デジタイザーによって各粒子の軌跡 を読み，粒子速度を求めた。Fig. 2のように測定部の 領域を 8 分割し, $\mathrm{i}$ 領域の代表粒子速度 $u_{\mathrm{pi}}$ は次式で 計算した。
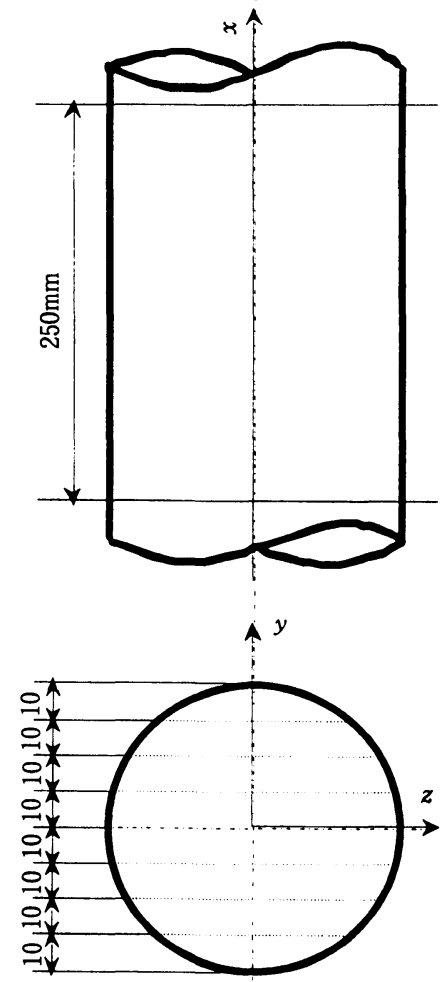

Unit : mm

Fig. 2 Schematic of measuring domain

$$
u_{\mathrm{pi}}=\frac{1}{N_{\mathrm{i}}} \sum_{j=1}^{N_{\mathrm{i}}} u_{\mathrm{pij}}
$$

ここで, $N_{\mathrm{i}}$ は i 領域に含まれる粒子数, $u_{\mathrm{pij}}$ は i 領域 の $\mathrm{j}$ 番目粒子の速度である。全領域内の粒子の平均速 度 $U_{\mathrm{p}}$ は次式で計算した。

$$
U_{\mathrm{p}}=\frac{1}{\sum_{\mathrm{i}=1}^{8} N_{\mathrm{i}}} \sum_{\mathrm{i}=1}^{8} \sum_{\mathrm{j}=1}^{N_{\mathrm{i}}} u_{\mathrm{pij}}
$$

ここで， $\sum_{\mathrm{i}=1}^{8} N_{\mathrm{i}}$ は全領域内の粒子数の総和である。

測定区間における各領域の相対粒子濃度分布 $\rho_{\text {si }} /$ $\rho_{\mathrm{s} 0}$ は次式で計算した。

$$
\frac{\rho_{\mathrm{si}}}{\rho_{\mathrm{s} 0}}=\left(\frac{A}{a_{\mathrm{i}}}\right) \frac{N_{\mathrm{i}}}{\sum_{\mathrm{i}=1}^{8} N_{\mathrm{i}}}
$$

ここで, $\rho_{\mathrm{s} 0}$ は全領域内の粒子の平均濃度, $A$ は管断 面積, $a_{\mathrm{i}}(\mathrm{i}=1,2 \ldots 8)$ は各領域の断面積である。

なお，写真を細かくみると粒子が重なった場合はほ とんどなかった。また，測定区間内での軸方向の粒子 
速度变化は無視した。

本研究に用いた固体粒子は, 平均粒径 $3.2 \mathrm{~mm}$, 真 密度 $946 \mathrm{~kg} / \mathrm{m}^{3}$, 浮遊速度 $8.44 \mathrm{~m} / \mathrm{s}$ のポリエチレン ペレットである。浮遊速度は内径 $80 \mathrm{~mm}$ の鉛直管で の䒠測值である。実験は平均空気速度 $U_{\mathrm{a}}$ が $9 \sim 25$ $\mathrm{m} / \mathrm{s}$ の範囲で行った。粒子上空気の質量流量比であ る混合比 $m$ が $0.2 \sim 0.7$ である。入口スワール数 $S_{0}$ が $0.38,0.68,0.94$ の 3 種類の案内羽根式旋回流発生器 を使用した。

本実験の不確かさ解析は, 要素誤差要因として, (1) 生力と差压変換器の校正に伴う誤差, (2)增幅器とA/ D 変換ボードによるデータ収集請差, (3)デジタイザー とカメラの䛊差を考虑して行った。その結果, 不確か さは, 平均空気速度 $U_{\mathrm{a}}$ では $99 \%$ 包括度で $8.9 \%$, 粒子速度 $u_{\mathrm{pi}}$ では $99 \%$ 包括度で $3.32 \%$ となった。

\section{3. 実験結果と考察}

\section{1 全圧損失}

直線流との比較のため, 前報 ${ }^{1.5)}$ と同様, 旋回流発 生器による圧力損失を含めた全圧損失 $\Delta P_{\mathrm{t}}$ を考え る。すなわち, 旋回流発生器前の鎮静管之管出口の間 をとり， $\Delta P_{\mathrm{s}}$ を鎮静管の壁面静压として， $\Delta P_{\mathrm{t}}$ は次式 で求めた。

$$
\Delta P_{\mathrm{t}}=\Delta P_{\mathrm{s}}+\frac{1}{2} \rho\left[\left(D / D_{0}\right)^{4}-1\right] U_{\mathrm{a}}^{2}
$$

ここで, $D_{0}$ は鎮静管直径で $156 \mathrm{~mm}, D$ は輸送管直 径で $80 \mathrm{~mm}$ である。

Fig. 3 に, $G_{\mathrm{s}}=0.03 \mathrm{~kg} / \mathrm{s}$ について全压損失 $\Delta P_{\mathrm{t}}$ と 平均空気速度 $U_{\mathrm{a}}$ の関係を入口スワール数 $S_{0}$ をパラ

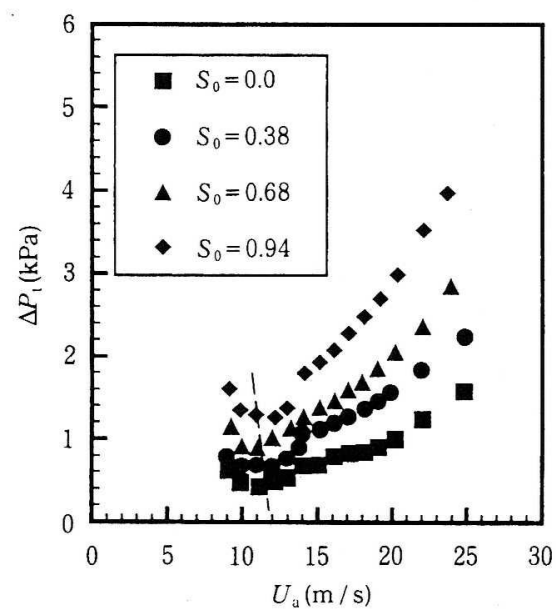

Fig. 3 Total pressure drop $\left(G_{\mathrm{s}}=0.03 \mathrm{~kg} / \mathrm{s}\right)$

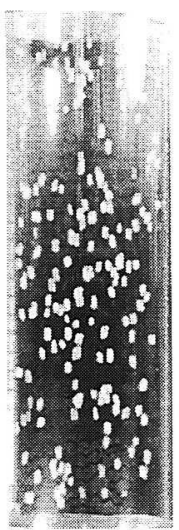

(a) $x=0.7 \mathrm{~m}$
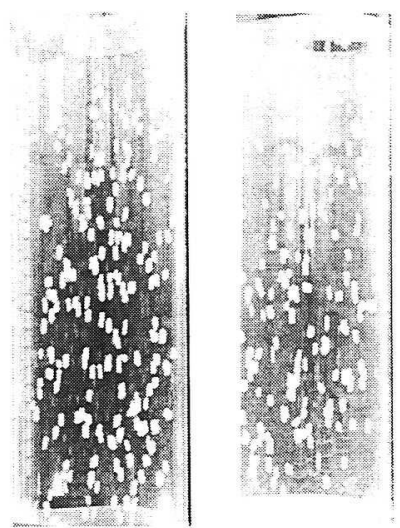

(b) $x=5.7 \mathrm{~m}$

(c) $x=11.7 \mathrm{~m}$

Fig. 4 Flow patterns of axial gas-solid flow $\left(U_{\mathrm{a}}=10 \mathrm{~m} / \mathrm{s}, G_{\mathrm{s}}=0.03 \mathrm{~kg} / \mathrm{s}, S_{1)}=0.0\right)$

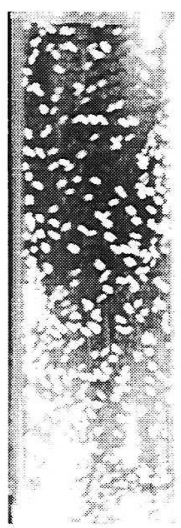

(a) $x=0.7 \mathrm{~m}$

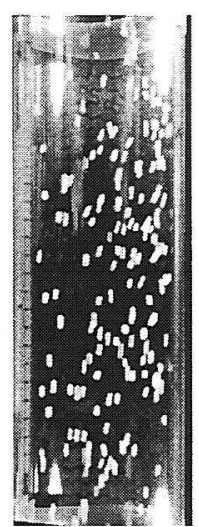

(b) $x=5.7 \mathrm{~m}$

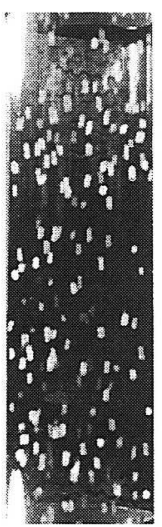

(c) $x=11.7 \mathrm{~m}$
Fig. 5 Flow patterns of swirling gas-solid flow $\left(U_{\mathrm{a}}=10 \mathrm{~m} / \mathrm{s}, G_{\mathrm{s}}=0.03 \mathrm{~kg} / \mathrm{s}, S_{0}=0.68\right)$

メータとして示す。図から，高速域では，旋回流空気 輸送の全圧損失は大きいが， $U_{\mathrm{a}}$ の減少に伴い急減 し，ある空気速度で最小值をもつことがわかる。一般 に, 直線流空気輸送では $\Delta P_{\mathrm{t}}$ の最小值の空気速度（以 下最適速度之呼ぶ）は安全輸送速度と考えられ, 輸送 エネルギーの節約, 管路の摩耗および被輸送物の破砕 の減少という観点から重要な風速である。Fig. 3 から $G_{\mathrm{s}}=0.03 \mathrm{~kg} / \mathrm{s}$ の場合, 旋回流の最適速度は直線流よ り小さく, 旋回流が強いほど最適速度は小さくなる傾 向が見られる。

\section{2 粒子の流動状態}

Fig. 4 と Fig. 5 は，供給器よりそれぞれ $0.7 \mathrm{~m} ， 5.7$ $\mathrm{m}$ 㧍よび $11.7 \mathrm{~m}$ での, 直線流 $\left(S_{0}=0.0\right)$ と旋回流 $\left(S_{0}=0.68\right)$ における粒子の運動軌跡の写真を示す。 


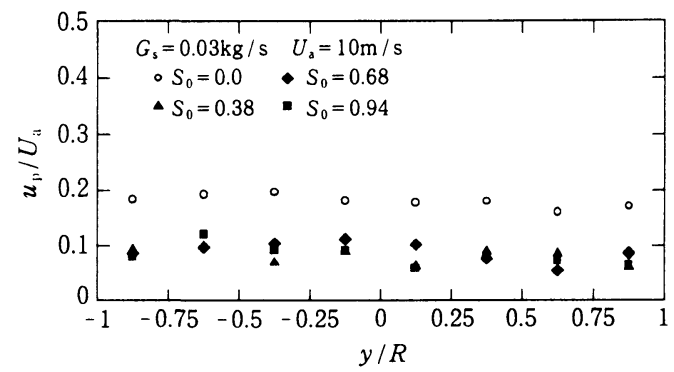

(a) at $x=0.7 \mathrm{~m}$

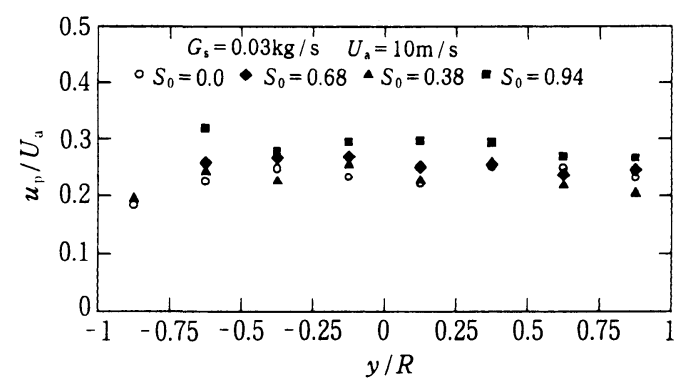

(b) at $x=5.7 \mathrm{~m}$

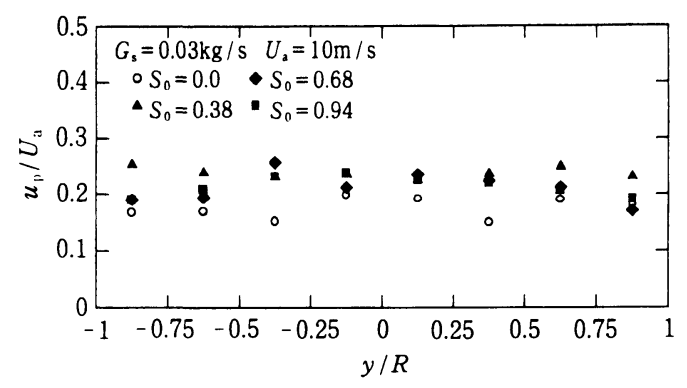

(c) at $x=11.7 \mathrm{~m}$

Fig. 6 Cross-sectional distribution of particle velocity

Fig.4から，0.7m での粒子運動は，直線流ではほ ぼ管軸に平行であるが, 旋回流では, 粒子は周方向に 旋回させられながら流動していることがわかる。旋回 流ではさらに, 低速域のとき高濃度の管壁流状態が現 れている。 $5.7 \mathrm{~m}$ では旋回流の周方向成分が減衰する ため, 粒子の旋回状態は弱くなっている。供給器より $11.7 \mathrm{~m}$ 下流では旋回流の周方向成分は更に弱くな り，粒子の運動状態は直線流とほぼ同じになる。

\section{3 管断面の粒子の速度分布之濃度分布}

Fig. 6 および Fig. 7 は各測定位置 $x=0.7 \mathrm{~m}, 5.7 \mathrm{~m}$ お よび $11.7 \mathrm{~m}$ における $U_{\mathrm{a}}=10 \mathrm{~m} / \mathrm{s}$ での旋回流および 直線流について, 管断面の粒子の速度と濃度分布を比 較したものである。鉛直管ではほぼ軸対称が成り立っ ていると考えられる。Fig.6のまとめ方では, 左右端

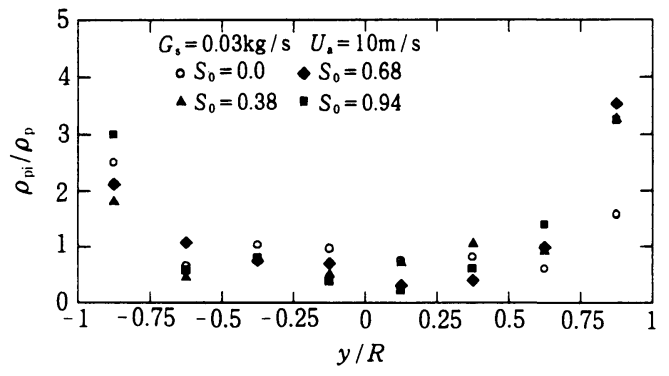

(a) at $x=0.7 \mathrm{~m}$

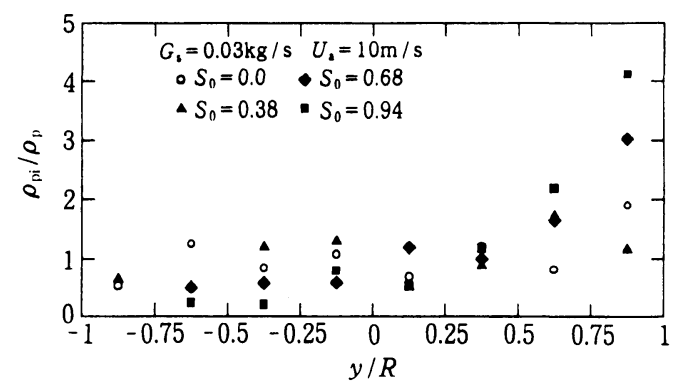

(b) at $x=5.7 \mathrm{~m}$

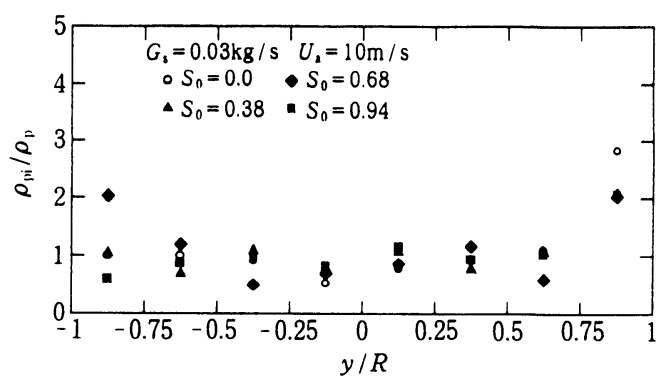

(c) at $x=11.7 \mathrm{~m}$

Fig. 7 Cross-sectional distribution of particle concentration

はほぼ管壁近傍に対応し, 中心に向かうにつれ, 各半 径位置の粒子速度を平均していることになる。Fig. 6 から粒子速度分布に関しては, 場所および旋回の強さ に関係なく，ほぼ均一な分布であるといえる。Fig. 7 より濃度分布は旋回流と直線流とも管壁付近で高くな っていることがわかる。この傾向は旋回流で強いと見 られる。 $x=5.7 \mathrm{~m}$ で旋回流は片側に高濃度の分布が 現れる。これは粒子が壁面を旋回しながら輸送されて いることを示す。

\section{4 管断面の平均粒子速度}

Fig. 8に，粒子供給部から $0.7 \mathrm{~m} ， 5.7 \mathrm{~m}$ および 11.7 $\mathrm{m}$ の位置における断面平均粒子速度 $U_{\mathrm{p}}$ と平均空気速 度 $U_{\mathrm{a}}$ の関係を入口スワール数をパラメータとして示 す。 

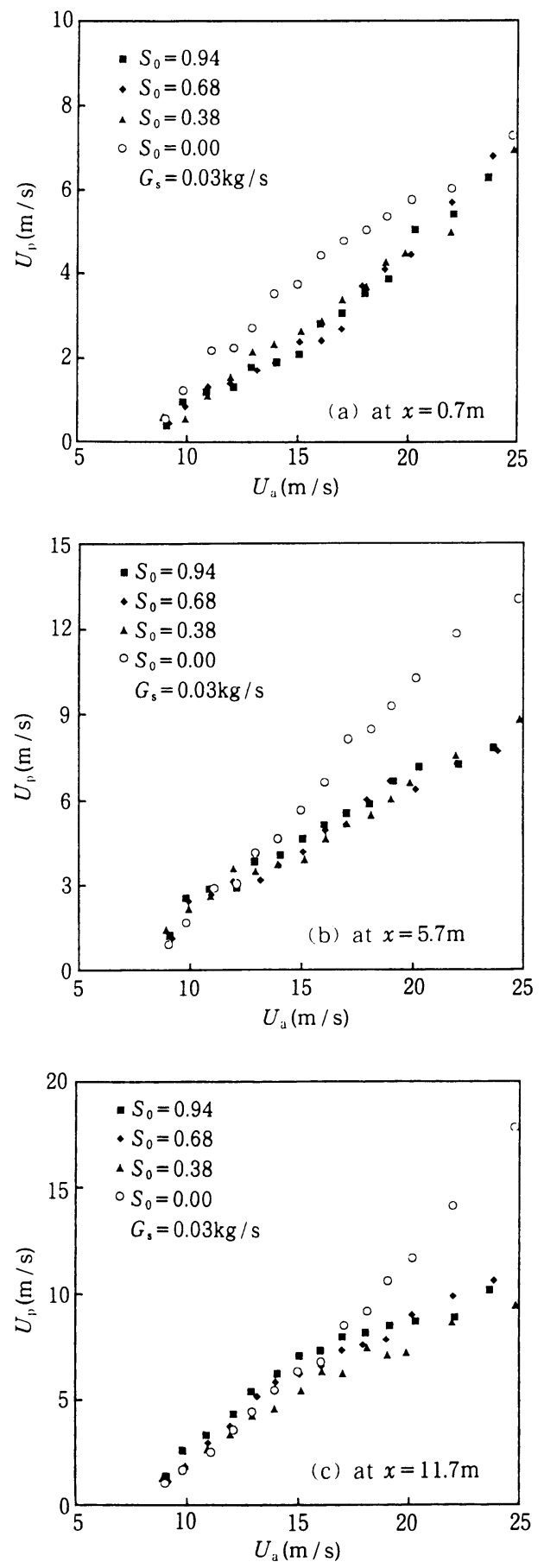

Fig. 8 Mean particle velocity versus mean gas velocity

$x=0.7 \mathrm{~m}$ （Fig. 8 (a)）では，高速域で各旋回流と直 線流の $U_{\mathrm{p}}$ はほぼ同じであるが, $U_{\mathrm{a}}$ を下げていくと旋 回流の $U_{\mathrm{p}}$ の方が小さくなり, $U_{\mathrm{a}}=16 \mathrm{~m} / \mathrm{s}$ 付近でそ
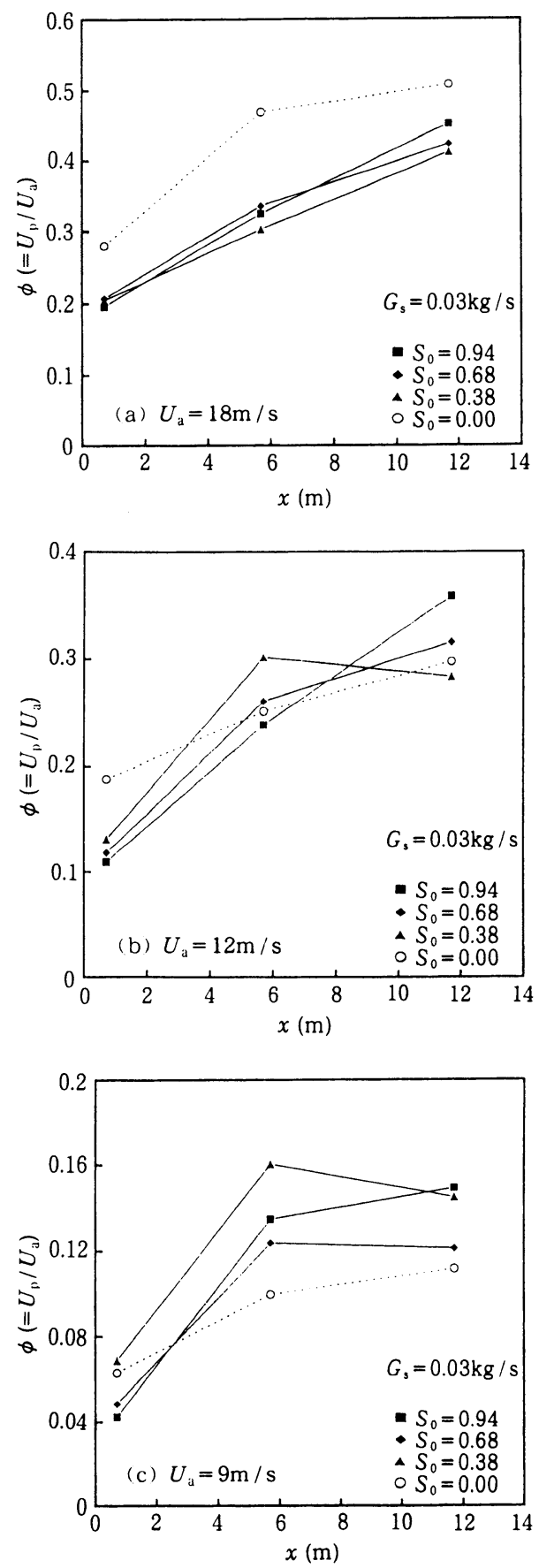

Fig. 9 Axial distribution of mean velocity ratio

の差は最大となる。さらに $U_{\mathrm{a}}$ を減少するとその差は 小さくなり, $U_{\mathrm{a}}=9 \mathrm{~m} / \mathrm{s}$ 付近で旋回流と直線流の $U_{\mathrm{p}}$ はほぼ同じとなる。閉塞速度の実験結果 ${ }^{1.5)}$ からも, これ以下の速度では旋回流の $U_{\mathrm{p}}$ は直線流のものより 大きくなることと予想される。 
$x=5.7 \mathrm{~m}$ においては, 高速域では旋回流の $U_{\mathrm{p}}$ は直 線流よりかなり小さいが, $U_{\mathrm{a}}$ を下げると，その差は 減少し, $U_{\mathrm{a}}=12 \mathrm{~m} / \mathrm{s}$ 以下で旋回流の $U_{\mathrm{p}}$ は逆に大き くなる。

さらに, 下流 $(x=11.7 \mathrm{~m})$ でもやはり高速域では 依然として直線流の $U_{\mathrm{p}}$ はかなり高いが, $U_{\mathrm{a}}$ の減少に よりその差は小さくなる。低速 $\left(U_{\mathrm{a}}<16 \mathrm{~m} / \mathrm{s}\right)$ では 強い旋回流 $\left(S_{0}=0.94\right)$ の $U_{\mathrm{p}}$ は直線流より大きくな っていることがわかる。

以上より， $U_{\mathrm{a}}$ が大きいとき旋回の影響はかなり下 流まで残っており，一方， $U_{\mathrm{a}}$ が小さいとき下流では 旋回流の $U_{\mathrm{p}}$ は直線流より大きく加速性がよいことが わかる。このことは, 旋回流が直線流より低速で輸送 できることを裏づけている。

Fig. 9 は $U_{\mathrm{a}}=18 \mathrm{~m} / \mathrm{s}, 12 \mathrm{~m} / \mathrm{s}$ および $9 \mathrm{~m} / \mathrm{s}$ にい て, 管軸に沿门平均粒子速度比 $\phi\left(\phi=U_{\mathrm{p}} / U_{\mathrm{a}}\right)$ の変化 を, 入口スワール数をパラメータとして示したもので ある。 $U_{\mathrm{a}}=18 \mathrm{~m} / \mathrm{s}$ (Fig.9 (a)) では, $\phi$ は下流に向か って旋回流, 直線流とも増加していることがわかる。 旋回流では粒子は周方向に旋回させられながら流動し ているため, 全体的に直線流の $\phi$ は大きくなってい る。加速域で強い旋回流 $\left(S_{0}=0.94\right)$ の $\phi$ は小さい が, 出口付近では逆にほかの旋回流より高くなってい る。他方, 直線流では $\phi$ の増加率は加速域で大きく, 下流で小さくなる傾向がみられる。

$U_{\mathrm{a}}=12 \mathrm{~m} / \mathrm{s}$ では, Fig.9 (b)のように, $x=0.7 \mathrm{~m}$ と $x=5.7 \mathrm{~m}$ の間で旋回流の $\phi$ の増加率は直線流より大 きくなっている。 $x=0.7 \mathrm{~m}$ 付近で旋回流の $\phi$ は直 線流より小さいが, $x=6 \mathrm{~m}$ 付近で旋回流 $\left(S_{0}=0.68\right.$ と $\left.S_{0}=0.38\right)$ の $\phi$ は逆に高くなっている。出口付近 では強い旋回流 $\left(S_{0}=0.94\right)$ も直線流より高くな り，申は旋回が強いほど大きいことがわかる。旋回流
$S_{0}=0.38$ のは下流で減少する傾向が現れる。

$U_{\mathrm{a}}$ が $9 \mathrm{~m} / \mathrm{s}$ に下がると (Fig.9 (c)), 旋回流の加速 は全体的に大きく, $x \geq 3 \mathrm{~m}$ では旋回流の $\phi$ は直線流 より高くなっている。下流で $(x>6 \mathrm{~m})$ 旋回流 $\left(S_{0}=\right.$ 0.68 と $\left.S_{0}=0.38\right)$ の $\phi$ の増加率は減少する傾向がみ られる。

以上より, 旋回流では空気速度が減少すると, 粒子 の加速域は短くなることがわかる。本実験の範囲で は, 旋回流が弱いほど加速域が短くなる傾向にあった が, 極めて旋回が弱い場合には加速域も直線流の場合 に近づくと予測でき，旋回流 $\left(S_{0}=0.38\right)$ 上り弱い ある場合において加速域は最小になると考えられる。 このように，直線流と比べて低速になるほど旋回流の 粒子加速域は短くなるが, その間の $\phi$ 増加率は直線 流よりはるかに大きく, 結果として旋回流の閉塞速度 は減少することと考えられる。

\section{4. 結 論}

低濃度鉛直管内旋回流空気輸送の実験を行い, 粒子 供給点から $0.7 \mathrm{~m}, 5.7 \mathrm{~m}$ および $11.7 \mathrm{~m}$ の 3 点で粒子 速度と濃度分布を測定し, 直線流と比較して以下の結 論を得た。

（1）空気速度が大きな場合には，旋回流では直線流に 比べて粒子の加速は抑制されるが, 空気速度が小さ な場合には, 旋回流により粒子の加速は促進され， 加速に要する距離が短縮される。

（2）本実験の範囲では, 旋回流が弱いほど粒子の加速 域が短くなる傾向がみられる。

（3）旋回流の粒子の断面速度分布はほぼ均一で, 濃度 分布については管壁付近で高くなる。

終りに, 実験にご協力頂いた九州工業大学の卒研生 の立石克彦および堤谷睦夫の両君に謝意を表す。

\section{References}

1) Li, H., Y. Tomita and K. Funatsu: "Research of Swirling Flow Pneumatic Conveying System in a Horizontal Pipeline (1st, Report, Pressure Drop and Flow Patterns)", Transactions of The Japan Society of Mechanical Engineers, 58 (B), 1599- 1604 (1992)

2 ) Li, H. and Y. Tomita : "Research of Swirling Flow Pneumatic Conveying System in a Horizontal Pipeline (3rd Report, Coefficients of Power Consumption and Additional Pressure Drop)", Transactions of The Japan Society of Mechanical Engineers, 59 (B), 756761 (1993)

3) Li, H., Y. Tomita and K. Funatsu : "Research of Swirling Flow Pneumatic Conveying System in a
Vertical Pipeline (Coefficients of Power Consumption and Additional Pressure Drop) ${ }^{n}$, Transactions of The Japan Society of Mechanical Engineers, 60 (B), 802-806 (1994)

4 ) Li, H., Y. Tomita and K. Funatsu : "Research of Swirling Flow Pneumatic Conveying System in a Vertical Pipeline (Overall Pressure Drop and Flow Patterns) ${ }^{n}$, Transactions of The Japan Society of Mechanical Engineers, 60 (B), 1263-1268 (1994)

5 ) Li, H. and Y. Tomita : "An Experimental Study of Swirling Flow Pneumatic Conveying System in a Horizontal Pipeline”, ASME Journal of Fluids Enginneering, 118, 526-530 (1996) 
6 ) Li, H. and Y. Tomita : "An Experimental Study of Swirling Flow Pneumatic Conveying System in a Vertical Pipeline", ASME Journal of Fluids Engineering, 120, 200-203 (1998)

7 ) Li, H. and Y. Tomita : "Research of Swirling Flow Pneumatic Conveying System in a Horizontal Pipeline (2nd, Report, Particle Velocity and Concentration Profiles )", Transactions of The Japan Society of Mechanical Engineers, 59 (B), 411-418 (1993)

8 ) Li, H. and Y. Tomita: "Particle Velocity and Concentration Characteristics in a Horizontal Dilute Swirling Flow Pneumatic Conveying", Powder
Technology (in press).

9 ) Li, H. and Y. Tomita: "A Numerical Simulation of Swirling Flow Pneumatic Conveying in a Horizontal Pipeline", Transactions of The Japan Society of Mechanical Engineers, 60 (B), 2431-2438 (1994)

10) Li, H. and Y. Tomita : "Numerical Simulation of Swirling Gas-Solid Two-Phase Flow in a Vertical Pipeline", Transactions of The Japan Society of Mechanical Engineers, 62 (B), 3810-3817 (1996)

11) Li, H. and Y. Tomita : "Characteristics of Swirling Flow in a Circular Pipe", ASME Journal of Fluids Engineering, 116, 370-373 (1994) 